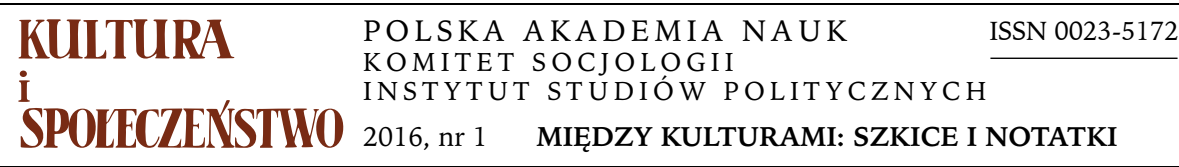

KATARZYNA KOŚĆ-RYŻKO

Instytut Archeologii i Etnologii PAN

\title{
KONSTRUOWANIE TOŻSAMOŚCI W WARUNKACH OBCOŚCI KULTUROWEJ. PRZYPADEK MAŁOLETNICH UCHODŹCÓW Z CZECZENII W POLSCE
}

„Każdy człowiek jest pod pewnymi względami:

- podobny do wszystkich ludzi,

- podobny do niektórych ludzi,

— niepodobny do żadnego z nich..."

Clyde Kluckhohn, Henry A. Murray Personality in Nature, Society and Culture

\section{WSPÓŁCZESNE WYZWANIA KULTUROWE}

W ostatnim czasie Europa stała się sceną znacznych przeobrażeń politycznych, społecznych i kulturowych. Otwarte granice między krajami Unii Europejskiej z jednej strony, a pogłębiająca się destabilizacja polityczna $\mathrm{w}$ wielu państwach Afryki, Azji i Bliskiego Wschodu $z$ drugiej $-z$ brutalnymi wojnami i katastrofą humanitarną - sprzyjają migracjom ludzi na masową skalę. Eskalacja i dynamika mobilności skierowanej w stronę Starego Kontynentu rodzi uśpione lęki - przed utratą dobrobytu (materialnego i symbolicznego) oraz konsekwencjami zmian (demograficznymi i kulturowymi). Poziom napięcia i niepokoju społecznego oddaje termin, którym w mediach określa się obserwowane zjawisko - kryzys migracyjny.

Potrzeba minimalizowania negatywnych skutków mobilności (są bowiem i pozytywne, o czym się obecnie zapomina) stanowi bodaj największe wyzwanie dla Europy od czasu zakończenia drugiej wojny światowej. Państwa zachodnie, 
bez względu na wewnętrzne problemy, stanowią atrakcyjny azyl dla ludzi znękanych wojną i permanentnym zagrożeniem życia. W trudnym położeniu znajdują się zwłaszcza dzieci i młodzież uchodźcza, których wychowywanie w sytuacji traumy i nagłego opuszczenia rodzinnych stron staje się bardziej złożone. Szczególne wyzwanie dla opiekunów odpowiadających za przygotowanie ich do życia stanowi kwestia pokoleniowego generowania dziedzictwa kulturowego i budowania identyfikacji etnicznej w warunkach obcości kulturowej. Problemy te dotyczą także uchodźców ${ }^{1}$ z Czeczenii (Ząbek, Łoziński 2008, s. 129-132), wśród których w latach 2009-2014 prowadziłam badania terenowe ${ }^{2}$. Nie tracą one na aktualności, zwłaszcza w obliczu nasilającej się ksenofobii i radykalizacji postaw przeciwników polityki integracyjnej i haseł wielokulturowości.

Problematyka akulturacji i integracji społecznej cudzoziemców, choć niezwykle ważna, do opinii publicznej przebija się na ogół dopiero wtedy, gdy dochodzi do burzliwych konfliktów między „gośćmi” i „gospodarzami”. Aby nie sięgać do ostatnich tragicznych zamachów z Paryża i Brukseli, przywołam wcześniejsze zdarzenie mające miejsce 15 kwietnia 2013 r. w Bostonie, gdzie na trasie maratonu doszło do eksplozji dwóch bomb. W wyniku śledztwa odpowiedzialnością za zamach obarczono dwóch braci czeczeńskiego pochodzenia - Dżohara i Tamerlana Carnajewów, którzy na mocy Konwencji Genewskiej przebywali wraz z rodziną w Stanach Zjednoczonych jako uchodźcy ${ }^{3}$. Informacje te sprowokowały lawinę pytań o to, jaką wiedzę mają rządy państw na temat cudzoziemców, którym udzielają schronienia. W wątpliwość podano również wskaźniki akulturacji dotychczas uznawane za trafny i rzetelny miernik udanej integracji (tj. znajomość języka, wykształcenie, bliskie relacje ze społeczeństwem przyjmującym). Okazało się bowiem, że nie są one miarodajne. Jako przykład podawano wspomnianych zamachowców, powszechnie uważanych za wyjątkowo dobrze zaadaptowanych do środowiska zamieszkania. Młodszy $z$ braci studiował medycynę na prestiżowej uczelni, cieszył się sympatią wielu przyjaciół, starszy zaś był żonaty z kobietą przez media określaną mianem

1 Terminu tego używam na określenie zarówno cudzoziemców ubiegających się o status uchodźcy, jak i osób z uregulowaną sytuacją prawną korzystających z różnych form ochrony międzynarodowej.

2 Tekst ten powstał na podstawie badań przeprowadzonych w ramach projektu finansowanego przez NCN (nr NN 109218136) kierowanego przez autorkę przy współudziale dr Izabeli Czerniejewskiej (Centrum Badań Migracyjnych). Część tez i wniosków jest wynikiem wspólnych badań i analiz, które prezentowałyśmy po raz pierwszy na I Kongresie Antropologicznym w Warszawie (październik 2013).

3 Według definicji Konwencji Genewskiej uchodźcą jest osoba, która „[...] na skutek uzasadnionej obawy przed prześladowaniem z powodu swojej rasy, religii, narodowości, przynależności do określonej grupy społecznej lub z powodu przekonań politycznych przebywa poza granicami państwa, którego jest obywatelem, i nie może lub nie chce z powodu tych obaw korzystać z ochrony tego państwa, albo która nie ma żadnego obywatelstwa i znajdując się na skutek podobnych zdarzeń poza państwem swojego dawnego stałego zamieszkania nie może lub nie chce z powodu tych obaw powrócić do tego państwa" (art. 1A ust. 2 Konwencji Genewskiej z 1951 r.). 
„typowej amerykańskiej dziewczyny wywodzącej się z klasy średniej” ${ }^{4}$. Szok obywateli pozbawionych poczucia bezpieczeństwa podsycały wypowiedzi zwolenników polityki etnicystycznej na „starym” i „nowym” kontynencie, wyrażające sprzeciw wobec niekontrolowanego napływu imigrantów. Argumentem przytaczanym jako uzasadnienie ich stanowiska była między innymi dotycząca starszego z braci wypowiedź teściów, którzy rzekomo przyznali w mediach: „Po horrorze w Bostonie wiemy już, że tak naprawdę nigdy nie poznaliśmy Tamerlana Carnajewa" 5 .

Wywołana w toku tych wydarzeń dyskusja skłoniła mnie do przyjrzenia się kwestii kreowania tożsamości i budowania poczucia przynależności etnicznej w środowisku małoletnich uchodźców z Czeczenii w Polsce. Zainteresował mnie zwłaszcza wpływ w różny sposób deklarowanych i manifestowanych afiliacji na proces przystosowania kulturowego do miejscowych warunków społecznych. Zastanawiałam się nad wpływem formacyjnym, jaki na ich samookreślenie ma sytuacja, w której się znaleźli, a także sam fakt bycia uchodźcą. Kluczowe w tym kontekście stało się pytanie o to, czy tożsamość małoletnich cudzoziemców budowana jest $\mathrm{w}$ procesie enkulturacji ${ }^{6}$ i przekazywania tradycyjnych wzorów funkcjonowania oraz wartości pozytywnie waloryzowanych w miejscu pochodzenia (w pierwszej kulturze), czy też składa się z elementów nabytych $\mathrm{w}$ drodze akulturacji ${ }^{7}$. W tym przypadku byłaby ona konstruowana na zasadzie kolażu - połączenia elementów kultury kraju pochodzenia i kultury obecnego miejsca osiedlenia, przefiltrowanych przez indywidualny zasób transnarodowych doświadczeń jednostki i "lustro społeczne" ${ }^{8}$. Efektem jest powstanie tożsamości złożonej (Taylor 2005), którą cechuje otwartość, niedokończoność, płynność (Bauman 2005, 2007, s. 49-70). Dlatego też trudno

${ }^{4}$ Zob. www.fakt.pl/Historia-zona-Tamerlana-bombera-z-Bostonu,artykuly,208672,1.html [24. 04.2013].

5 www.wiadomosci.onet.pl/swiat/usa-dzochar-carnajew-uslyszal-zarzuty-za-zamach-w-, 1,5473 825,wiadomosc.html [13.5.2013].

6 Terminu „enkulturacja” używam na określenie „wychowania kulturowego” będącego procesem nabywania mentalnych reprezentacji (wierzeń, wiedzy, itp.) oraz wzorów zachowań wymaganych, aby funkcjonować jako członek danej kultury. Jest to odpowiednik socjalizacji na poziomie kultury i odbywa się w dzieciństwie oraz wczesnej młodości jako część procesu wychowawczego i edukacyjnego. Zob. Rhum 2006, s. 149-150; por. Herskovits 1948, s. 10-14; M. Mead 1963.

${ }^{7}$ Zgodnie $z$ przyjętym założeniem akulturacja pozostaje $\mathrm{w}$ bezpośredniej relacji do procesu kształtowania się tożsamości cudzoziemca (zwłaszcza małoletniego) i jest procesem równoległym do enkulturacji. Termin ten definiuje się jako całość wieloaspektowych zmian kulturowych, którym podlega jednostka, rodzina, wspólnota lub społeczność $\mathrm{w}$ reakcji na kontakt $\mathrm{z}$ odmiennym systemem kulturowym w trakcie bezpośredniej konfrontacji. Zmniejszeniu dystansu kulturowego nie musi towarzyszyć symetryczne zmniejszenie dystansu społecznego. Sytuacja taka ma miejsce, gdy jedna z grup odmawia drugiej prawa do akulturacji; zob. Glick 2006.

8 Teoria "lustra społecznego" (social mirror theory) zakłada, że niezbywalnym elementem samowiedzy jednostki jest reakcja na nią innych ludzi. Zgodnie z tym założeniem, ludzie definiują i nadają znaczenie swoim wewnętrznym przekonaniom przez konfrontację z punktem widzenia innych". Zob. G. H. Mead 1975; por. Whitehead 2010, s. 1. 
mówić o wspólnej tożsamości generacyjnej przedstawicieli grupy etnicznej żyjącej poza granicami kraju, gdyż jej zrąb tworzy się w bezpośredniej relacji do miejsca osiedlenia i osobniczych więzi społecznych. Może się więc okazać, że jedynym podzielanym doświadczeniem pokoleniowym małoletnich cudzoziemców pochodzących z tego samego kraju jest „bycie uchodźcą” (por. Garewicz 1983, s. 7-87). Fakt ten - kluczowy dla autobiografii i samookreślenia w większym stopniu łączy ich $z$ innymi cudzoziemcami w podobnej sytuacji (nawet reprezentującymi kultury odmienne od ich rdzennej) niż z osobami tej samej narodowości, ale bez doświadczenia migracyjnego.

Poszukując odpowiedzi na postawione pytania poddałam analizie zewnętrzne wskaźniki identyfikacji etnicznej, kulturowej i religijnej cudzoziemców (przejawiające się w ubiorze, zwyczajach, praktykach dnia codziennego, zachowaniach, zagospodarowaniu przestrzeni, emblematach, symbolach) oraz wypowiedzi zarejestrowane $\mathrm{w}$ trakcie wywiadów, ujawniające określone cechy samoidentyfikacji. W efekcie opracowane zostały: model budowania samookreślenia młodych uchodźców oparty na dwóch alternatywnych strategiach (rekonstrukcji i dekonstrukcji) oraz quasi-model „tożsamości uchodźcy”.

\section{PROCEDURA I KONTEKST BADAŃ}

Badania dotyczyły osób pochodzących z rodzin starających się o otrzymanie statusu uchodźcy w Polsce oraz takich, które pomyślnie przeszły tę procedurę i osiedliły się na terenie naszego kraju. W większości byli to obywatele Rosji pochodzący z byłych republik radzieckich: Czeczenii, Dagestanu, Osetii, Inguszetii, Gruzji, Kirgistanu, Armenii, sporadycznie z innych krajów. Cechą charakterystyczną tej grupy była jej duża rotacyjność i częste przemieszczenia - zarówno w obrębie polskich ośrodków, jak i innych państw europejskich; wynika to z poszukiwania lepszych warunków życia oraz chęci mieszkania wśród bliskich i krewnych. Okazało się, że dla wielu osób Polska jest wyłącznie przystankiem w podróży, co nie sprzyja wysokiej motywacji do nauki języka i adaptacji (Rafalik 2012, s. 21).

Obserwacją objęte były przede wszystkim dzieci w wieku od 6 do 14 lat i młodzież od 15 do 20 roku życia, w mniej więcej równoważnej liczbie, jeśli chodzi o płeć, a także ich rodziny. W sumie przebadano ponad 150 osób, a grupa najmłodszych liczyła około 80. Wśród młodzieży zdecydowanie przeważali mężczyźni, gdyż byli bardziej dostępni, co wynika z norm zwyczajowych związanych z okresem dorastania i kulturowych ról płciowych przyjętych wśród muzułmanów. Dojrzewające dziewczęta i młode kobiety mają ograniczone możliwości swobodnego kontaktowania się z obcymi. Nie jest również dobrze widziane, aby spędzały czas z rówieśnikami, dlatego najczęściej włączane są w prace domowe i opiekuńcze nad rodzeństwem (Adger-Adajew 2005, s. 214-215). Znacznie rzadziej można je też spotkać na zewnątrz, poza domem, a i wtedy na ogół w towarzystwie innych kobiet. 
Przyjęta w stosunku do młodzieży klauzula wiekowa jest umowna, gdyż badanie obejmowało wyłącznie osoby stanu wolnego, a wiele dziewcząt w tym wieku jest już zamężnych. Natomisat młodzi mężczyźni na uchodźstwie dłużej pozostają w kawalerskim stanie niż tradycyjnie, co jest skutkiem wojny, zmian demograficznych i ubóstwa materialnego nie pozwalającego im na branie odpowiedzialności za swoją rodzinę i klan. Życie poza ojczyzną zmienia dotychczasowy model funkcjonowania rodziny czeczeńskiej i prowadzi do przeobrażeń w sferze obyczajowości. W opinii wielu Czeczenów jest to drastyczna degradacja odwiecznego ładu społecznego, której konsekwencje mogą okazać się nie mniej destrukcyjne niż wojna czyniąca $z$ nich bezdomnych nędzarzy.

Podstawę analizy stanowił materiał zebrany podczas wielostanowiskowych etnograficznych badań terenowych prowadzonych w kilku centrach recepcyjnych — zwanych potocznie ośrodkami uchodźczymi — między innymi w Warszawie, Białymstoku, Lininie, Mosznej, Brwinowie, Czerwonym Borze, Grupie k. Grudziądza, Kolonii Horbów oraz w innych miejscowościach zamieszkiwanych przez cudzoziemców z przyznaną ochroną międzynarodową (m.in. Łomży i Pruszkowie). Procedura metodologiczna przewidywała zastosowanie zróżnicowanego asortymentu technik i narzędzi badawczych, w tym: obserwacji uczestniczącej, wywiadów pogłębionych, autofotografii (polegającej na udostępnieniu badanym aparatu z prośbą o robienie zdjęć w swoim otoczeniu) oraz nagrań audiowizualnych dokumentujących codzienne i odświętne życie uchodźców. W odniesieniu do dzieci zastosowałam również technikę psychorysunku (m.in. rysunek rodziny, „mój świat”, „przyszłość”), a w odniesieniu do młodzieży kwestionariusz psychologiczny (Test Stosunków Szkolnych). Zebrany materiał okazał się niezwykle bogatym i różnorodnym źródłem informacji o dużej wartości merytorycznej, zwłaszcza w przypadku analizy jakościowej, choć niekoniecznie ilościowej - ze względu na nierównoważność grupy (pod względem wieku, płci, długości pobytu w Polsce, okoliczności opuszczenia ojczyzny).

Głównym założeniem przyświecającym realizacji projektu było poznanie sytuacji uchodźców z terenów postradzieckich w Polsce (ze szczególnym uwzględnieniem dzieci i młodzieży) oraz analiza ich szans integracyjnych, przy uwzględnieniu różnic kulturowych i religijnych. Celem praktycznym było przyczynienie się do wypracowania przez stronę polską własnych strategii adaptacyjnych oraz metod prewencji w sytuacjach konfliktowych, które uwzględniałyby lokalną specyfikę (w znaczeniu spuścizny historycznej, położenia geopolitycznego, tradycji i kultury oraz możliwości finansowych i prawnoadministracyjnych).

Doświadczenia poprzedzające realizację projektu badawczego, polegające na pracy w charakterze wolontariusza w ośrodku na Bielanach (nie istniejącym od połowy $2010 \mathrm{roku}$ ), pokazały mi, że młodzi ludzie wskutek przeżyć, których doświadczyli przed opuszczeniem swojego kraju, zderzenia z kulturą przyjmującą i trudności adaptacyjnych poddają redefinicji wcześniejsze samookreślenie. 
Szczególnie wrażliwe okazały się wymiary o dużym międzygrupowym potencjale dyferencyjnym - określające narodowość, pochodzenie etniczne, religijność.

Przystępując do badań przyjęłam tezę, że procesy identyfikacyjne (tożsamościowe) i ich skutki wywierają istotny lub nawet determinujący wpływ na adaptację małoletnich uchodźców do nowych warunków życia. Poszukiwanie odpowiedzi na pytanie „kim jestem” zmusza bowiem do niełatwych konfrontacji z własną przeszłością i teraźniejszością, a także do negocjacji treści i wartości, które nadadzą kierunek przyszłości.

\section{TRANSMISJA WZORÓW I IDENTYFIKACJA}

Identyfikacja małoletnich cudzoziemców w znacznym stopniu zależy od postawy akulturacyjnej przyjętej w ich najbliższym środowisku reprezentowanym przez członków grupy własnej (rodziców, opiekunów, krewnych pozostałych w kraju) oraz od przedstawicieli kraju osiedlenia (pracowników administracji ośrodkowej, nauczycieli, polskich kolegów, sąsiadów), a także polityki integracyjnej kraju przyjmującego ${ }^{9}$. Konstruowana przez nich tożsamość odzwierciedla stosunek do kraju osiedlenia oraz podejście wobec nich ze strony członków społeczeństwa przyjmującego. Od tego ostatniego w znacznym stopniu zależy, czy wzmacniają oni/budują symboliczną więź z własnym narodem, religią i kulturą pochodzenia, czy też przejmują niektóre wzory funkcjonowania przyjęte w kraju osiedlenia. Nie bez znaczenia jest, czy czynią to pod wpływem własnej decyzji, czy też nacisków którejś z grup - w efekcie konformizmu lub zbiorowego interesu wspólnoty etnicznej. Sprawia to, że pozornie ten sam skutek może być osiągnięty za sprawą różnych motywacji (wzmacniających lub osłabiających prestiż cudzoziemców), co pociąga za sobą odmienne konsekwencje w sferze przekonań, zachowań i ich trwałości. Przykładem może być rezygnacja $z$ noszenia tradycyjnych ubiorów; czym innym jest, gdy wynika z liberalizacji poglądów, czym innym, gdy jej powodem jest lęk przed agresją i chęć „wtopienia się" w tłum, a jeszcze czymś innym, gdy zostaje arbitralnie narzucona przez grupę dominującą.

Proces samookreślenia dzieci i młodzieży w zasadniczym stopniu dokonuje się przez enkulturację i akulturację, na styku dwóch różnych światów domowo-rodzinnego i szkolno-rówieśniczego. Funkcjonowanie w nowym środowisku kulturowym $\mathrm{w}$ znacznym stopniu zależy od siły przekazu i wpływu wywieranego na małoletnich przez te dwa środowiska. Nie zawsze są one kompatybilne i na ogół jednostka musi wybierać, która ścieżka rozwoju własnej tożsamości jest jej bliższa. Istnieje kilka możliwości, spośród których za najbardziej typowe uznałam trzy: opcja kompromisowa, polegająca na wybiór-

9 Ten rodzaj trójstronnych zależności charakteryzuje interaktywny model akulturacji (interactive acculturation model, IAM) spopularyzowany przez Richarda Y. Bourhisa i in. (1997, s. 369-386). 
czym podejściu do treści i wartości reprezentowanych przez kulturę rdzenną i negocjowaniu ich przyjęcia lub odrzucenia; konfrontacyjna, cechująca się oporem wobec ,jarzma tradycji” i narzuconych wzorów kulturowych, wyjazd do innego kraju traktowany jest wówczas jako okazja do zmiany dotychczasowego sposobu życia; konformistyczna wobec członków własnej kultury, polegająca na niekwestionowanym, wiernym naśladownictwie i internalizacji wzorów rdzennej kultury nawet wtedy, gdy nie przystają one do miejscowych norm i zasad pożycia społecznego.

Tożsamość tworząca się w wyniku tych oddziaływań i znamiennych dla nich komunikatów perswazyjnych może cechować otwartość na nową kulturę lub zamknięcie i ukryta wrogość. Niedocenianie roli wychowania kulturowego w tym procesie jest dużym błędem, mogącym prowadzić do poważnych konsekwencji, co unaoczniają zwłaszcza sytuacje konfliktowe (np. spowodowane utratą przez cudzoziemców dotychczasowych przywilejów), gdy dochodzą do głosu nagromadzone emocje i frustracja spowodowana poczuciem wykluczenia.

\section{WSKAŹNIKI TOŻSAMOŚCI}

Tożsamość uchodźcza, według przyjętego wzoru, jest sumą trzech identyfikacji - etnicznej, kulturowej i religijnej. Choć nie wyczerpują one możliwości samodefinicyjnych jednostki, to zostały uznane za kluczowe $\mathrm{w}$ procesie adaptacji i za najczęstsze źródło trudności w tym zakresie. Identyfikacja $\mathrm{w}$ tym znaczeniu jest to samodefinicja jednostki i jej sposób wyrażenia podmiotowego „ja” przez zbiorowe „my” (Kłoskowska 1992, s. 13-141; Sadowski, Czerniawska 1999, s. 15-17). Proces ten przebiega w pewnych określonych konwencją (kulturową) granicach, których przekroczenie może prowadzić nawet do wykluczenia z grupy. Identyfikację buduje się nie tylko na określonych przynależnościach, ale również na „nieprzynależnościach”. Zdarza się nawet, że fundament tożsamości zbudowany jest na zanegowania określonych filiacji (np. nie jestem/nie jesteśmy tacy jak inni rodacy).

W psychologii społecznej przyjmuje się, że identyfikacja jest ważnym mechanizmem wpływu społecznego i konformizmu — polega na tym, że pragnienie upodobnienia się do osoby lub grupy prowadzi do przejmowania (uwewnętrzniania) jej przekonań i wartości oraz uznawania ich za własne ${ }^{10}$. Wpływ ten działa nawet pod nieobecność jego źródła (w tym przypadku własnej grupy etnicznej), a nagrodą za dopasowanie się jest wzrost samooceny. W odniesieniu do badanych cudzoziemców przyjmuje to postać prawidłowości - im niższa samoocena, tym silniejsze dążenie do identyfikacji z grupą lub reprezentowanymi przez nią wartościami (zapewniającymi dobre samopoczucie). Tłumaczy to również, dlaczego wielu przebywających poza granicami kraju radykalizuje

10 Elliot Aronson (2007, s. 25, 35-37) mechanizm ten nazywa efektem wujka Karola (Uncle-Charlie phenomenon); zob. też Aronson 1997, s. 39-43, 50-58 
się w swoich afiliacjach, na przykład nie będący religijnymi nagle zaczynają czynnie praktykować lub nie angażujący się w życie społeczne, nagle stają się aktywistami lub działaczami narodowymi. Identyfikacja może pełnić również rolę mechanizmu obronnego, polegającego na zastępczym realizowaniu potrzeb lub dążeń przez rozbudowywanie i umacnianie więzi z podmiotem, który te dążenia uosabia (Hammack 2008, s. 227-229). W przypadku uchodźców można się zastanawiać, czy stymulowanie identyfikacji narodowej (tutaj: „czeczeńskości") nie jest przykładem działania zastępczego w obliczu marginalizacji doświadczanej w obcym kraju. Wskazywać na to mogą wypowiedzi świadczące o idealizacji poprzedniego miejsca zamieszkania, jego kultury i znaczenia na arenie międzynarodowej oraz próby mitologizacji i megalomania.

Budowanie tożsamości małoletnich uchodźców polega na wzmacnianiu określonych identyfikacji przez dobór wskaźników istotnych z punktu widzenia jednostki i grupy. Nierzadko, gdy cudzoziemiec czuje się w jakimś aspekcie swego samookreślenia zagrożony, to właśnie na nim koncentruje uwagę i wzmacnia go. Wywołuje to mechanizm zwrotny - nieufność wobec przybyszy ugruntowuje ich obawy i poczucie zagrożenia w nowym miejscu osiedlenia, co skutkuje zwiększeniem dystansu i narastającym brakiem ich akceptacji, a to $z$ kolei umacnia ich identyfikację etniczną, religijną lub kulturową - w zależności od tego, co stanowi główną oś podziału na swoich i obcych. Odbywa się to często poprzez swoistą "grę na symbolach” i mówiąc metaforycznie - przypomina teatr, w którym widzami (odbiorcami komunikatów) są przedstawiciele kultury przyjmującej, a aktorami - cudzoziemcy.

Wybór wskaźników tożsamości podyktowany jest ich rolą i znaczeniem dla sposobu funkcjonowania cudzoziemców w nowym miejscu osiedlenia; jest on umowny i przyjęty na potrzeby interpretacyjne. Jego składowe przenikają się wzajemnie i jedno zachowanie może być egzemplifikacją różnych identyfikacji, w ramach wspólnego spektrum (np. zwyczaje religijne wiążą się z kulturą, a ta nie jest wolna od akcentów narodowych). W charakterystyce wyróżnionych identyfikacji pomocne okazały się wskaźniki materialne i symboliczne, zdefiniowane na podstawie obserwacji uczestniczącej i rozmów z badanymi.

Opisując identyfikację etniczną przyjęłam, iż jest to silne przywiązanie do kraju pochodzenia, symboli i wartości przezeń uosabianych (takich jak wolność, męstwo, odwaga, honor, godność, gościnność), co przejawia się w deklarowaniu i manifestowaniu przynależności narodowej w warstwie zewnętrznej (np. przez określone elementy stroju i symbole w przestrzeni prywatnej i publicznej) oraz wewnętrznej (w sferze postaw i poglądów przekładających się na określone zachowania i wybory). W przypadku Czeczenów najczęściej obserwowanym znakiem więzi z ojczyzną są umieszczane w różnych miejscach napisy: Czeczenia, Nochczi, Iczkeria oraz symbol flagi (malowany na ścianach, odzieży, w zeszytach dziecięcych, na ciele), której kolorystyka ma istotne znaczenie (zielony to islam, biały czystość, a czerwony krew przelana przez Czeczenów). Osoby z silną identyfikacją etniczną na ogół są niechętne 
wobec zmian, mają poczucie własnej wyższości, skłonne są do etnocentryzmu, a nawet ksenofobii.

Identyfikację kulturową zdefiniowałam jako przywiązanie do tradycji, zwyczajów i wzorów kulturowych związanych z krajem pochodzenia. Jej typowe wskaźniki to: znajomość języka ojczystego i spuścizny kulturowej reprezentowanej przez twórczość artystyczną (literacką, muzyczną, plastyczną) oraz przypisywanie im dużej wartości, kultywowanie tradycji i zwyczajów w sferze praktyki życia codziennego ${ }^{11}$.

Analogicznie do powyższych identyfikacja religijna oznacza silne przywiązanie do wiary i związanych $z$ nią wartości oraz manifestowanie i deklarowanie przynależności konfesyjnej w warstwie zewnętrznej (przez praktyki i symbole) i wewnętrznej (postawy, wierzenia, światopogląd). Charakterystyczną cechą osób z silną identyfikacją religijną jest dążenie do życia zgodnego $z$ zasadami i normami określonymi przez wyznanie, wierność autorytetom duchowym, przestrzeganie określonego kodeksu etyczno-moralnego, kultywowanie praktyk religijnych (bywa, że rygorystyczne).

Przyjęte wskaźniki są rodzajem znaków, które w zależności od kontekstu można odczytywać na różnych płaszczyznach i poziomach (synchronicznie i diachronicznie). Ten sam fenomen kulturowy (przedmiot, zachowanie, zdarzenie) może wskazywać jedną identyfikację lub też wszystkie naraz; jego rola jest instrumentalna względem niej. Implikuje to konieczność każdorazowego poznania okoliczności wykorzystywania danego atrybutu w celu zakomunikowania określonej treści. Uznanie czegoś za pewnik może być mylące, a poznanie subiektywnych intencji zaskakujące (np. powszechna znajomość przez uchodźców popularnego kaukaskiego tańca lovzar, niezwykle chętnie prezentowanego przez Czeczenów w różnym wieku, nie tyle wynika z umiłowania folkloru, co — jak przyznat jeden $z$ respondentów w wieku szkolnym — jest to sprawdzony sposób zwrócenia na siebie uwagi, wywarcia wrażenia na płci przeciwnej i „pokazania się od lepszej strony"). Intencje te są w pełni zrozumiałe i nie ma w nich nic nagannego, zwłaszcza przy uwzględnieniu położenia uchodźców w Polsce i tego, że nieczęsto mają możliwość zaprezentowania „atrakcyjnego oblicza" swojej odmiennej kultury. Wykorzystują więc każdą okazję do poprawy wizerunku i podniesienia prestiżu grupowego.

Większość analizowanych wskaźników identyfikacji przejawia się w sferze publicznej (jawnej, ogólnodostępnej), a część wyłącznie w sferze prywatnej - zarezerwowanej dla swoich i sporadycznie, częściowo udostępnianej innym (nie-Czeczenom, niewiernym, kobietom). W tej pierwszej uchodźcy prezentują się zazwyczaj w sposób, w jaki chcą być postrzegani. Istotną rolę odgrywa tutaj komunikacyjna funkcja stroju oraz cele przyświecające nadawcy komunikatu, które nie zawsze są łatwe do odczytania. W pewnym sensie jest to odgrywa-

11 Termin „praktyki życia codziennego” stosuję w znaczeniu teoretycznym nadanym mu przez Michela de Certeau $(1984,2008)$. 
nie określonej roli, służącej zaprezentowaniu siebie jako określonej osoby zacnej, wierzącej, silnej, zamożnej, wpływowej. Częste są na przykład starania młodych mężczyzn, chcących wzbudzić respekt i uznanie, którzy korzystają z każdej okazji, aby prężyć muskuły, demonstrować sprawność fizyczną i waleczność, na przykład podczas pokazów sztuk walki MMA (mixed martial arts, $z$ ang. mieszane sztuki walki) ${ }^{12}$.

Sfera prywatna $\mathrm{w}$ większym stopniu niż publiczna służy manifestowaniu wyznawanych wartości. Zdarza się, że nie są one zgodne z przekazem nadawanym w sferze publicznej, a nawet aprobowane społecznie. Przykładem są napisy i rysunki na ścianach korytarzy w ośrodkach uchodźczych i prywatnych pokojach, odwołujące się do Koranu, walki o niepodległość, znanych bojowników i partyzantów. Nierzadko wyrażają one złość, bunt i frustrację spowodowaną swoim położeniem lub są sposobem zawłaszczenia przestrzeni przez daną grupę etniczną (rodzajem Hyde Parku, w którym każda ściana w ośrodku należy do innej nacji). Nie chodzi przy tym o akty wandalizmu, które są stosunkowo rzadkie w tych miejscach, ale o zbiorową manifestację poglądów lub formę protestu. Sens takiego przekazu często jest zakodowany i czytelny tylko dla niektórych, tak jak inskrypcje w języku czeczeńskim i arabskim lub tajemnicze daty i symbole, których pełnego znaczenia nie ujawniają nawet otwarte pytania - zbywane lub mętnie ripostowane.

To tylko wybrane przykłady ilustrujące, że do poznania rzeczywistych tendencji tożsamościowych nie wystarczy opis funkcjonowania cudzoziemców w sferze publicznej, ale niezbędne jest dokonanie korelacji między wizualnymi atrybutami tożsamości i mentalnymi ich reprezentacjami, które mogą (ale nie muszą) ujawniać się $\mathrm{w}$ rozmowie oraz symbolach $\mathrm{w}$ najbliższym otoczeniu uchodźcy. Dopiero na ich podstawie można pozyskać jakąkolwiek wiedzę na temat zinternalizowanych wartości odpowiadających za kluczowe wybory podejmowane obecnie i w przyszłości.

\section{KREOWANIE WIZERUNKU JAKO ELEMENT BUDOWANIA IDENTYFIKACJI}

Zewnętrzne przejawy samookreślenia młodych uchodźców skłaniają do wniosku, że część z nich w większym stopniu wynika z lokalnej mody panującej w środowisku osiedlenia niż z tradycji i zwyczajów przyjętych w kulturze pochodzenia. Są one również odbiciem trendów odzieżowych panujących $\mathrm{w}$ danym miejscu, wynikających $z$ dostępności określnych towarów. Przykładem może być styl ubioru zaobserwowany w trakcie badań terenowych prowadzonych w latach 2011-2012 w ośrodku w Czerwonym Borze, gdzie ku zdziwieniu kadry pracowniczej centrum recepcyjnego oraz lokalnej społeczno-

12 Dyscyplina ta za sprawą czeczeńskich zawodników o międzynarodowej sławie wyrosła w ostatnim czasie do rangi narodowej (w Polsce głównie dzięki Mamedowi Khalidowi i Aslambekowi Saidovi). 
ści wiele kobiet i dziewczynek nosiło hidżaby — tradycyjne chusty arabskie. Było to zastanawiające, gdyż nie są one elementem stroju zwyczajowo przyjętym w Czeczenii, ponadto nawet $\mathrm{w}$ tradycyjnych krajach muzułmańskich obowiązek skrywania włosów dotyczy na ogół dorosłych kobiet. Próba zgłębienia genezy i znaczenia owego detalu wizerunkowego okazała się nieoczywista i dosyć skomplikowana. Interpretacje, jakie słyszałam od okolicznych mieszkańców, sugerowały, że jest to oznaka radykalizujących się postaw religijnych tutejszych cudzoziemców. Okazało się jednak, że wyjaśnienie to jest tyleż nietrafne, co niepełne. Dowodzi jednak, że ubiór jest ważnym źródłem informacji i swoistym kodem kulturowym - i jako taki ma znaczenie, choć nierzadko inne niż pierwotnie, stereotypowo zakładano. Niestety, wyjątkowo łatwo jest zasugerować się informacjami uzyskanymi od pierwszych rozmówców napotkanych w terenie. $Z$ wypowiedzi udzielonych przez pracowników ośrodka oraz Czeczenów przybyłych do Polski we wcześniejszych latach i mieszkających poza nim wynikało, że zaobserwowany nurt estetyczny jest fenomenem, który dotychczas nie występował $\mathrm{w}$ tym miejscu, a przynajmniej nie na taką skalę. Tłumaczenie go zbiorową konwersją religijną wydawało się nadinterpretacją, gdyż nie potwierdzały jej inne aspekty życia uchodźców. Wyjaśnienie przyszło znienacka i okazało się dosyć banalne, poza tym jego źródło leżało nie tyle w sferze sacrum, co profanum.

Ujawniło je skierowane do mieszkańców ośrodka pytanie dotyczące sposobów zaopatrywania się przez nich w odzież z symboliką etniczną: czapek, koszulek, pasków $z$ dużymi sprzączkami $z$ wypisanymi na nich alfabetem rosyjskim lub tureckim napisami Nochczi, Czeczenia lub Ikczeria, tunik damskich itp. W odpowiedzi usłyszałam, że regularnie odwiedza ich „objazdowy sklep” z turecką odzieżą, rozprowadzaną przez rodaka, w którym zazwyczaj zaopatrują się $\mathrm{W}$ ubrania produkowane specjalnie na „rynek czeczeński”. $\mathrm{Z}$ tego samego źródła pochodzą kolorowe chusty i hidżaby z Turcji, chętnie noszone przez tutejsze dziewczynki i część kobiet (Wybieralski 2014). Popularność ich wynika zarówno $z$ wzajemnego naśladownictwa, jak i częściowo $z$ chęci upodobnienia się do znanej wśród mieszkańców Kaukazu celebrytki Chrystal Callahan. Prowadzi ona popularne programy rozrywkowe w telewizji Grozny TV, które niezmiennie od kilku lat cieszą się dużą oglądalnością i są dostępne w internecie. Nie jest tajemnicą, że ta czarnoskóra modelka kanadyjskiego pochodzenia, wykreowana na gwiazdę popkultury przez specjalistów od PR prezydenta Ramzana Kadarowa, prowadzi programy propagandowe ${ }^{13}$, których oficjalnym celem jest promocja Czeczenii i zmiana jej wizerunku politycznego na „łagodniejszy”, bardziej atrakcyjny i otwarty na inność. W filmach nie unikano również propagowania islamu, do czego posługiwano się także wizerunkiem prezenterki i jej ekranowymi stylizacjami. Zazwyczaj występuje ona w kolorowych chus-

13 Najbardziej znane, dostępne na internetowej platformie YouTube to: „Chechnya Through The Eyes of Chrystal Callahan” oraz „Highlights of the Week with Chrystal Callahan”. 
tach wiązanych na głowie na kaukaską modłę i uosabia „nowoczesną kobiecość w tradycyjnej odsłonie". Mimo że przez niektóre środowiska (między innymi międzynarodowe organizacje humanitarne) Chrystal Callahan bywa krytykowana za pracę w Czeczenii i wspieranie rządów prorosyjskiego, antydemokratycznego prezydenta, wielu młodych ludzi (również uchodźców) uważa ją za „ikonę stylu" 14 .

Istotny wpływ na ośrodkową modę oraz przyjęte tam codzienne praktyki miało również przybycie do Czerwonego Boru wraz z rodziną, z zamiarem ubiegania się o azyl, imama wykształconego w Egipcie (Kość-Ryżko, Czerniejewska 2013, s. 130-155). W okresie swojego kilkutygodniowego pobytu wprowadził on wiele zmian, co podzieliło uchodźców na dwie grupy: zdecydowanych zwolenników i przeciwników narzuconych przez niego reguł. W trakcie pierwszej dłuższej wizyty w tym miejscu z niemałym zdziwieniem obserwowałam zasady pożycia przyjęte przez blisko połowę mieszkańców, zwłaszcza że wcześniej nie spotkałam się z podobnymi w żadnym innym ośrodku. Wśród nich znalazły się między innymi wegetariańska dieta, ciemna odzież i noszenie burek przez kobiety, długie brody i podgolone głowy mężczyzn, obowiązkowa modlitwa pięć razy dziennie $\mathrm{w}$ założonej $\mathrm{w}$ tym celu sali modlitw, nauka języka arabskiego (również dla dzieci). Choć wyjaśnienie tego fenomenu nie było łatwe, gdyż część rozmówców albo nie chciała mówić, albo przyznawała, że sama nie rozumie, co się tutaj dzieje, to po kilku miesiącach imam zniknął równie nagle, jak się pojawił, a wraz z nim większość wprowadzonych przez niego zasad. Decyzji o jego wyjeździe z Polski towarzyszył mały skandal, co podczas kolejnych pobytów w ośrodku znacznie rozwiązało języki moich rozmówców.

Zdarzenie to ilustruje powierzchowność, ulotność i nietrwałość niektórych zewnętrznych oznak przynależności, która nieustannie jest negocjowana i dopasowywana do potrzeb i możliwości cudzoziemców przebywających w obcym kulturowo otoczeniu. Kryterium nadrzędnym takiej modyfikacji staje się utylitaryzm i pragmatyzm, a w „czasie kryzysu” nawet kwestie identyfikacyjne $z$ fundamentalnych degradują się do instrumentalnych, co niesie ryzyko nadmiernych uproszczeń i przedwczesnych generalizacji, których powinni wystrzegać się zwłaszcza badacze. Doświadczenie to wyczuliło mnie na „kostium”, jaki w niektórych sytuacjach stanowią wykorzystywane przez małoletnich uchodźców zewnętrzne oznaki afiliacji i definicje samookreślające. Analiza zgromadzonych materiałów ujawniła także, że zarówno ubiór, jak i ogólny wizerunek uchodźców bywają rodzajem konwencji przyjętej w określonym celu, przy wykorzystaniu dostępnych środków. Zdarza się, że za jego pomocą próbują oni

\footnotetext{
14 Chrystal Callahan zarzuca się między innymi bycie „narzędziem propagandy” rządu czeczeńskiego, jednak według retoryki CNN - jest ona symbolem stabilności i pokoju po latach konfliktu w regionie. Zob. www.chrystalgrozny.blogspot.com/; www.youtube.com/watch?v=Nqp7P0 XEcX0; www.rferl.org/content/Canadian_Model_Unlikely_New_Face_Of_Chechen_TV/1928764. html [13.11.2013].
} 
osłabić (zatrzeć) więzi łączące z poprzednim miejscem zamieszkania oraz własną kulturą lub przeciwnie - zaakcentować je i w symboliczny sposób wzmocnić, na przykład chcąc podkreślić własną odrębność i inność. Celem bywa na ogół zyskanie akceptacji i aprobaty — albo ze strony członków własnej społeczności, albo miejscowych.

Kreowanie wizerunku i metamorfozy (fizyczne i światopoglądowe) są elementem rozwoju osobniczego i mobilności ludzkiej; w szczególny sposób łączą się jednak z doświadczeniem „cudzoziemskości”. Wynika to z jednej strony z poszukiwania własnej tożsamości, uzupełniania jej o nowe aspekty samowiedzy i redefinicji w zmienionych warunkach, a z drugiej z usilnego dążenia do stawania się określonym „kimś” i podążania za wyobrażeniem o sobie samym.

Obcość kulturowa i poczucie dewaluacji wartości grupy społecznej, której jest się członkiem - wynikające, według Baumana (2004, s. 28-29), głównie z rozpadu wspólnoty - wpływają na codzienne funkcjonowanie uchodźców i stawiają ich w obliczu fundamentalnych pytań, między innymi o to, co znaczy być Czeczenem, kobietą, mężczyzną, muzułmaninem, uchodźcą. Niepewność pojawiająca się w konsekwencji „zawalenia się” dotychczasowego życia rodzi konieczność stanięcia przed „lustrem” odzwierciedlającym „ja”, realne, idealne, zbiorowe oraz prywatne (Elliott 2007, s. 61-98). Uzyskana w ten sposób samowiedza jest konstytutywna dla tożsamości nieustannie konfrontowanej z rzeczywistością otaczającego jednostkę świata społecznego.

Wygląd zewnętrzny wraz ze składającymi się nań atrybutami (tj. postawa ciała, mimika, gestykulacja, styl ubioru, ogólna estetyka, schludność, fryzura, nakrycia głowy, biżuteria, akcesoria itp.) jest zbiorem określonych informacji zaadresowanych do konkretnego odbiorcy. Założenie to skierowało moją uwagę na sposoby kreowania image'u indywidualnego i zbiorowego przez młode pokolenie uchodźców oraz wykorzystywane w tym celu akcesoria i techniki. Jednym z najbardziej nieodłącznych „gadżetów” wizerunkowych, bez którego trudno sobie wyobrazić młodego Czeczena, jest telefon komórkowy - pełniący przy okazji rolę łącznika ze światem. Choć sam fakt jego posiadania nie jest niczym nadzwyczajnym i w dobie globalnego rozwoju telekomunikacji nikogo nie dziwi, to już sposoby jego wykorzystania i przypisywane mu znaczenie moga wywoływać u postronnego obserwatora konsternację. W swoim pierwotnym znaczeniu przedmiot ten jest neutralny, podobnie jak cel, któremu służy, czyli rozmowa i kontakt z ludźmi, jednak małoletni uchodźcy nie ograniczają się do tych podstawowych funkcji. Ważniejsza jest dla nich rola telefonu jako nośnika kluczowych informacji o posiadaczu i wyznacznika jego statusu. Symboliczne funkcje komórki pozostają w ścisłym związku z tradycyjnymi czeczeńskimi wartościami, takimi jak więzi społeczne - rodzinne i krewniacze, ustosunkowanie, szacunek i autorytet, zaufanie, zasobność, poinformowanie itp. Sprostanie tym wysokim standardom jest trudne $\mathrm{w}$ każdych warunkach, a już niewątpliwie w sytuacji odcięcia od własnych korzeni i życia w obcym środowisku kulturowym. Pomocny w tym, choć w ograniczonym stopniu, może być sprzęt 
elektroniczny: im lepszy - bardziej nowoczesny, lepiej wyposażony, wielofunkcyjny, a tym samym droższy - tym większa szansa, że spełni pokładane w nim nadzieje i pośrednio przyczyni się do polepszenia samopoczucia jego użytkownika.

Telefon komórkowy jest wizytówką właściciela i nierzadko powodem jego dumy; brak funduszy na karcie uniemożliwiający swobodne $z$ niego korzystanie staje się powodem wstydu i ośmieszających żartów ze strony znajomych. Jego posiadanie jest obowiązkowe nawet wtedy, gdy brakuje pieniędzy na wiele innych, zdawałoby się bardziej potrzebnych rzeczy. Środki na zakup nowego aparatu muszą się znaleźć w każdej rodzinie i wiedzą o tym nawet dzieci. Wyjaśnień jest kilka, a najbardziej oczywiste jest takie, że to jedyny i najbardziej sprawdzony sposób kontaktu z bliskimi w kraju i rozproszonymi po świecie. Podejścia do posiadania telefonu komórkowego nie zmienia nawet częsty zarzut $\mathrm{w}$ stosunku do uchodźców, że taki zakup ze skromnych środków finansowych przyznawanych w ramach comiesięcznej zapomogi jest czystym zbytkiem i rozrzutnością. Krytyka ta nie uwzględnia jednak kontekstu kulturowego, który rzuca nieco inne światło na cudzoziemców. Ich ogólne ubóstwo i ograniczony stan posiadania sprawiają, że jest to najczęściej jedyny „luksus”, na jaki mogą sobie pozwolić. Co więcej, zapewnia namiastkę bliskości z rodziną i odległymi przyjaciółmi, pozwala pozostawać $\mathrm{w}$ nimi $\mathrm{w}$ relacji i zachować pozory wpływu na ich życie, daje możliwość „statycznej aktywności” i załatwiania „ważnych spraw”, co jest szczególnie cenne dla osób zamieszkałych w ośrodku, $z$ ograniczoną możliwością przemieszczania się.

Częstotliwość dzwonienia telefonu i liczba znajomych w książce adresowej przekłada się na prestiż środowiskowy i estymę otaczającą jego użytkownika. Aparat komórkowy jest nieodłącznym towarzyszem wszystkich spotkań i rozmów. Zawsze leży na wierzchu, w dostępnym miejscu, co oznacza, że jego właściciel jest osobą oddaną swoim bliskim, gotową zawsze im służyć pomocą i radą, godną zaufania i skłonną do ofiarnej przyjaźni. Jeśli głośny dzwonek wielokrotnie przerywa rozmowę na dłuższy czas, to niezbity dowód, nie tyle braku dobrego wychowania, co tego, że jego właściciel „jest kimś”. Znaczy to, że cieszy się autorytetem, szacunkiem, ludzie się go radzą, dopytują o samopoczucie, pozdrawiają — jest ważny i ma wysoką pozycję we własnej grupie.

Komórka jest więc uwiarygodnieniem i wizytówką właściciela. Dlatego wiele starań wkłada się w jej personalizację, dążąc do tego, aby odzwierciedlała zainteresowania i gust posiadacza. Służą temu oryginalne tapety, zdjęcia, filmiki, muzyka i dzwonki - najczęściej w rytmie tradycyjnych pieśni czeczeńskich lub arabskiego popu. Wykorzystywana jest także do spraw poważniejszych. Zdarza się, że wydobywający się $z$ telefonu głos muezina przypomina o porze modlitwy. Można też zamówić aplikację z surami Koranu przesyłanymi codziennie $\mathrm{w}$ formie smsów lub inną, $\mathrm{z}$ przeglądem prasy opisującej najważniejsze wydarzenia w kraju i za granicą w języku rosyjskim. 
Widok młodych mężczyzn stojących grupkami na korytarzach lub siedzących przed ośrodkiem na ławkach i pochylonych nad swoimi „mobajlami” należy do codzienności. Jest to nie tylko jedna $z$ niewielu ogólnodostępnych rozrywek, ale też dzięki internetowi źródło zdobywania wiedzy. Masowy dostęp do telefonii komórkowej sprawia, że komunikacja między odległymi rejonami globu staje się możliwa, nie zmienia to jednak faktu, że sposoby jej wykorzystywania są uwarunkowane kulturowo i należy je interpretować w możliwie szerokim kontekście lokalnych znaczeń. Analogicznie, w przypadku uchodźców trudno właściwie zrozumieć rangę tego urządzenia w ich codziennym życiu bez odniesienia od tradycji i wartości kulturowych, których są spadkobiercami.

Akcesoria pomocne w budowaniu wizerunku samego siebie, cieszące się największą popularnością wśród małoletnich uchodźców, można podzielić na kilka umownych kategorii ze względu na narrację, jaką pozawerbalnie pomagają tworzyć: patriotyczne, militarne, nowoczesne (w wariancie kobiecym i męskim), wyznaniowe, tradycyjnie kaukaskie. Służy temu przede wszystkim odzież i jej różne elementy, dodatki i akcesoria, na przykład: bluzy i t-shirty z różnymi napisami, naszywkami, emblematami, a w przypadku kobiet tradycyjne tuniki, modne sukienki, spódnice, bluzki eksponujące wdzięki; poza tym nakrycia głowy: chusty, hiżdżaby, czapki ( $\mathrm{z}$ daszkiem, wiązane z tyłu głowy, dziergane), paski męskie $z$ dużymi sprzączkami, biżuteria kobieca i męska (sygnety, zegarki, bransolety). Znamienne są również popularne stylizacje: w przypadku młodych mężczyzn najczęstsza jest sportowa i elegancka, choć spotyka się również „mudżahedińską”, dla której charakterystyczny jest ubiór w czarnym kolorze, krótkie włosy, długa broda, sygnet, tiubitiejka (krymka) lub szydełkowa czapeczka. Preferowana estetyka odzwierciedla w pewnym stopniu postawę adaptacyjną cudzoziemców i staje się formą manifestacji poglądów, gotowości integracyjnej oraz symbolicznej przynależności - etnicznej, kulturowej, religijnej, europejskiej. Komunikat nadawany w ten sposób jest na ogół czytelny i mówiący „kim chcą być” nadawcy, jak chcą być widziani. W tym sensie staje się on regulatorem dystansu w relacjach $z$ miejscowymi — zachęca lub zniechęca do kontaktu, określa zasady, uwspólnia lub wyróżnia.

Interesująca jest również zaobserwowana maniera pozowania do zdjęć: z symbolami narodowymi (flagami lub jej rysunkami na ciele), w miejscach wywołujących określone skojarzenia (przy pomnikach, na przykład przy żołnierzu w Muzeum Wojska w Białymstoku, na strzelnicy sportowej z bronia), w wymownych pozach („,na modelkę”, ,na Mameda Khalidowa” czy posiadacza dóbr luksusowych widocznych w tle). Zachowania te można uznać za naiwny sposób autoprezentacji bądź próbę manipulacji odbiorcą za pomocą spreparowanego zgodnie $z$ własnymi przekonaniami obrazu, na przykład ilustrującego sukces adaptacyjny. Rekwizyty wykorzystywane na fotkach służą poprawie samooceny, odwzorowują marzenia i wyobrażenia uchodźców o szczęściu i spełnieniu życiowym. Nie dziwi więc, że większość zdjęć przechowywanych w telefonach komórkowych młodych Czeczenów przedstawia ich jako silnych, odważnych, 
walecznych i bogatych, kobiety zaś jako piękne, atrakcyjne, majętne i nowoczesne (co można uznać za przejaw akulturacji).

Popularną techniką służącą cudzoziemcom do kreowania własnego wizerunku jest zamieszczenie pozowanych zdjęć na stronach serwisów społecznościowych. Pod nimi dopisywane są stosowne informacje, na przykład „to ja na zakupach”, „moje auto”, „to my na przyjęciu”, „moja sukienka” itp. Najczęściej jednak zostawia się wolne miejsce na wyrażenie opinii (aprobaty) oglądających. Dopiero gdy zgromadzi się stosowną liczbę pozytywnych komentarzy, „portrety” stają się kompletne, zyskują na wartości i można je pokazywać w szerszym gronie, identyfikując się z przedstawionymi na nich osobami. Tematyka i otoczenie (tło) zdjęć, bez względu na płeć modeli, są dosyć typowe i powtarzalne, co — jak się wydaje - nie stanowi ich wady: wystawy sklepowe (jubilerskie, odzieżowe, $\mathrm{w}$ przypadku mężczyzn również z militariami), samochody, nieruchomości, postery kinowe. Za pomocą fotografii budowany jest przekaz ,jestem (chcę być) tym, co widzisz na zdjęciu”, ,jestem w miejscu, które daje mi dostęp do tych dóbr". Stosunkowo rzadko, jak można odnieść wrażenie, sesje traktowane są z przymrużeniem oka; na ogół ich bohaterowie wykorzystują je do konfrontacji z opiniami na swój temat, pytając na przykład „myślisz, że będę mogła to kiedyś mieć”, „dobrze mi z tym”, „naprawdę tak wyglądam". Fotografie stają się pośrednim sposobem zdobywania wiedzy na swój temat i potwierdzania tożsamości; pomagają przyjrzeć się „sobie” na zewnątrz (na zdjęciu) oraz w oczach innych.

\section{(DE)KONSTRUKCJA I (RE)KONSTRUKCJA - PRZECIWSTAWNE MODELE SAMOOKREŚLENIA}

Uchodźcy z Czeczenii stanowią bardzo niejednorodną grupę, co potwierdziły przeprowadzone badania; dotyczy to zwłaszcza sposobów funkcjonowania $\mathrm{w}$ polskim społeczeństwie. Część osób cechuje otwartość, gotowość do akulturacji i akceptacja zmian zachodzących w ich "kulturowym genotypie”. Reprezentanci tej grupy chętnie korzystają z możliwości oferowanych przez zamieszkanie poza granicami kraju, w nowym miejscu i starają się pogodzić style życia przyjęte $\mathrm{w}$ obu kulturach, wybierając $\mathrm{z}$ nich to, co odpowiada ich potrzebom i celom. Wyróżnia ich często indywidualizm, niezależność myślenia, odwaga głoszenia poglądów odmiennych od większości i nonkonformizm - cechy, które w przypadku narodowości czeczeńskiej, ceniącej sobie wartości kolektywne i więzi grupowe (rodowe), nie należą do postaw powszechnych i aprobowanych społecznie, zwłaszcza w przypadku kobiet. Cechy te często pomagają im w przeciwstawianiu się własnej grupie etnicznej i próbom sprawowania przez nią kontroli. Wśród takich osób najczęściej też obserwuje się skłonność do budowania tożsamości metodą dekonstruowania.

W przypadku młodych uchodźców polega ona na afirmacji nowej kultury kosztem starej oraz stopniowym aprobowaniu i asymilowaniu jej treści (po- 
staw, wzorów zachowań itp.). W niektórych przypadkach jest to w pełni świadomy, trudny wybór, po którym nie ma już łatwego odwrotu, gdyż towarzyszy mu zerwanie lub niepodtrzymywanie więzi z kulturą pochodzenia oraz jej przedstawicielami na obczyźnie. Osoby takie spotykają się z potępieniem i stają się persona non grata w środowiskach reprezentujących wspólnotę narodową; nie mogą też liczyć na jej wsparcie w razie trudności, pozostawione zostają samym sobie i uważane za zdrajców. Zdarza się, że entuzjazm spowodowany opuszczeniem dotychczasowego miejsca zamieszkania jest krótkotrwały i po pierwszych trudnościach adaptacyjnych lub w wyniku presji środowiska następuje powrót „na łono” własnej kultury.

Charakterystyczną cechą tego sposobu budowania samookreślenia w nowych warunkach jest słabo rozwinięta identyfikacja etniczna, religijna i kulturowa, które najprawdopodobniej nie odgrywają znaczącej roli w nowym miejscu. Ważniejsze stają się identyfikacje wynikające z osobistych preferencji, a nie grupowych decyzji i poczucia powinności wobec własnej grupy etnicznej czy narodu, który dla wielu z nich stał się niezbyt realną, abstrakcyjną ideą ${ }^{15}$. Sprawia to, że osoby decydujące się na ten model tożsamościowy są negatywnie postrzeganie przez resztę społeczności czeczeńskiej — zwłaszcza tę jej część, która wybrała tożsamość (re)konstruowaną. Wiąże się to więc z ryzykiem utraty kontaktu $z$ diasporą i kulturą pochodzenia, poszukiwaniem alternatywnych afiliacji lub dążeniem do asymilacji ${ }^{16}$. Jednym $z$ efektów ubocznych preferencji dla tego modelu jest stopniowe wyłączanie się spod kontroli społecznej ${ }^{17}$, czego następstwem bywa większa swoboda obyczajowa i dopuszczanie się zachowań nieakceptowanych we własnej kulturze (tj. picie alkoholu, zachowania przestępcze).

Osoby preferujące ten model budują własną tożsamość według indywidualnego wzorca, co sprawia, że w przeciwieństwie do przedstawicieli tożsamości (re)konstruowanej, trudno jest mówić o treściach wspólnych dla jego reprezentantów. Każdy przypadek determinują osobiste doświadczenia i oczekiwania względem nowego miejsca zamieszkania. Strategia ta bywa zarówno efektem wyboru, jak i konieczności; ten drugi przypadek najczęściej dotyczy samotnych kobiet $z$ dziećmi, pozostających bez wsparcia rodziny i wspólnoty etnicznej,

15 Przykładem zastępczej afiliacji jest „identyfikacja uchodźcza”, która jest atrakcyjną alternatywą dla osób wrażliwych społecznie, poszukujących możliwości ekspresji buntu i zaangażowania się „W coś ważnego”. Charakterystyczne dla nich jest przekonanie o misji do spełnienia, która wynika $z$ osobistych doświadczeń. Osoby takie nierzadko stają się aktywistami współpracującymi $z$ organizacjami pozarządowymi i angażującymi się $w$ akcje humanitarne.

16 Symptomatyczne są wypowiedzi uchodźców o tym, że nie chcą mieć do czynienia ze swoimi rodakami w Polsce, ponieważ nie można im ufać oraz dyskredytujące ich jako prawdziwych/dobrych Czeczenów.

17 Kontrola społeczna chroni przed utratą wartości istotnych dla trwania i funkcjonowania wspólnoty narodowej, nakłada sankcje na zachowania nieaprobowane przez nią (nierzadko również przez społeczeństwo przyjmujące) i monitoruje proces akulturacji i enkulturacji. W zamian jednostka rezygnuje $z$ samostanowienia i preferencji adaptacyjnych zgodnych $z$ osobistymi celami i możliwościami. 
które zmuszone są porzucić wcześniejsze reguły genderowe i przyzwyczajenia kulturowe na rzecz biologicznego przetrwania. Konsekwencją może być jednak nasilająca się separacja, gdyż emancypacja kobiet, zwłaszcza wychowujących potomstwo w sposób niezgodny z tradycyjnymi normami, spotyka się z ostracyzmem, naganą i odrzuceniem przez „swoich”, a ze strony społeczności przyjmującej często też nie mogą liczyć na wsparcie i zrozumienie.

Strategią akulturacyjną najbardziej typową dla osób wybierających ten model budowania samookreślenia jest indywidualizm lub marginalizacja; optymalnie zaś integracja/asymilacja. W zasadniczym stopniu (istotniejszym niż $\mathrm{w}$ przypadku drugiego modelu) strategia ta zależy od postawy akulturacyjnej dominującej $\mathrm{w}$ społeczności przyjmującej. Wybór tożsamości (de)konstruowanej jest trudną, a nawet niewdzięczną drogą, okupioną wysokimi kosztami i niepewnością; łatwiej też tu o porażkę i odrzucenie przez dwie strony - swoich i obcych. W konsekwencji choć strategia akulturacyjna jest dla jednostki bardziej rozwojowa i stwarza lepsze możliwości adaptacji kulturowej, to niesie ze sobą większe ryzyko niepowodzenia.

\section{TOŻSAMOŚĆ (RE)KONSTRUOWANA}

Drugi model strategii akulturacyjnej małoletnich uchodźców został określony mianem tożsamości (re)konstruowanej. Termin ten, analogicznie jak wcześniejszy, występuje w metaznaczeniu i odnosi się do procesu budowania samookreślenia pod wpływem kontaktu $z$ inną kulturą, poniekąd od nowa, ale ze „starych elementów”, cechujących kulturę pochodzenia. Pojawiają się one w oderwaniu od pierwotnego kontekstu kulturowego (tradycji, historii, zwyczajów, środowiska) i występują w zmienionej konfiguracji, nadającej im zupełnie inne znaczenie. Fragmentaryczne treści kultury cudzoziemców są transplantowane na obcy grunt i występują jako rodzaj „replik kulturowych”, imitujących z różnym skutkiem oryginalne wzorce. Dotyczy to wzorów zachowania, stylów życia oraz wybranych tradycji obrzędowych, kulinarnych i innych. Odmienne warunki społeczno-kulturowe sprawiają jednak, że formowana w ten sposób „czeczeńskość” znacznie odbiega od pierwowzorów, których jest wiele i próba stworzenia typu idealnego i oryginalnego skazana jest na niepowodzenie.

Osoby reprezentujące ten model dążą do odtworzenia swojego poprzedniego świata w nowym miejscu osiedlenia. Dlatego też ich podejście do adaptacji kulturowej jest pełne rezerwy. Nie odrzucają jej, ale raczej niechętnie poddają się wpływom innej kultury, selektywnie korzystają z jej zasobów i w większym stopniu kierują się interesem grupowym niż oczekiwaniami „gospodarzy". Z przeprowadzonych rozmów wynika, że choć zależy im na tym, aby dobrze i zgodnie funkcjonować w danym kraju, to raczej na własnych zasadach. Dopóki obie kultury — rdzenna i nowa — są sobie dosyć bliskie pod względem wyznawanych wartości (tj. wiara w Boga, rola rodziny, bezpieczeństwo mate- 
rialne, szacunek dla życia ludzkiego) i preferowanych stylów życia (sposobów funkcjonowania społecznego), to relacje między nimi są zgodne. Problemy pojawiają się, gdy różnice, na przykład spowodowane zmieniającą się sytuacją polityczną, przyczyniają się do przeciwstawienia sobie obu grupy i antagonizowania ich. Przykładem mogą być sytuacje, w których wartości uniwersalne kulturowo stają się przedmiotem manipulacji ideologicznej i nabierają nowego znaczenia, jak religijność i wielodzietność, które choć akceptowane i pozytywnie waloryzowane $\mathrm{w}$ większości społeczeństw europejskich (zarówno na poziomie indywidualnym, jak i instytucjonalnym), w przypadku cudzoziemców stają się argumentem uzasadniającym niechęć wobec nich i strach przez ich przewagą liczebną.

Dla osób realizujących ten model konstruowania tożsamości charakterystyczna jest także niechęć wobec integracji i obawa przed zmianami w kodzie kulturowym. Zachowawczość wynika poniekąd z lęku przed utratą odmienności kulturowej i postępującą westernizacją najmłodszego pokolenia. W przypadku Czeczenów ma to związek z troską o zachowanie tradycji i obawami przed unicestwieniem ich narodu, który od wieków walczy o przetrwanie i samostanowienie. $Z$ tej perspektywy preferencje dla (re)konstruowania tożsamości dzieci i młodzieży są zrozumiałe.

Najczęściej odbywa się to na kilka sposobów, które dzielą się na bezpośrednie (wychowywanie w domu, modelowanie, przekazywanie wartości, kształtowanie postaw i wyuczanie określonych zachowań) (Ziemska 1979; Kawula, Brągiel, Janko 1997) i pośrednie (zaangażowanie w życie wspólnoty etnicznej, uczestniczenie w organizowanych w jej ramach aktywnościach, takich jak nauka języka, zajęcia taneczne, spotkania w meczecie, ograniczanie się towarzysko do przedstawicieli własnej kultury).

Podejście do akulturacji osób reprezentujących ten model jest minimalistyczne, a preferowana strategia to separacja. W przeciwieństwie do zwolenników tożsamości (de)konstruowanej skłonni są oni do integracji w sensie instytucjonalno-prawnym (dotyczącym codziennego funkcjonowania w danym państwie i korzystania z dóbr, tj. opieka medyczna, edukacja, zasiłek socjalny), niekoniecznie zaś kulturowym, wiążącym się z zaangażowaniem wykraczającym poza powierzchowne kontakty ze społecznością przyjmującą.

Stanowczo chciałabym jednak podkreślić, że „problem z uchodźcami” nie polega na tym, iż dążą oni do przekazania swoim potomkom więzi z narodem, kulturą czy religią - tego samego prawa oczekiwali bowiem również Polacy na przestrzeni lat dla swoich diaspor rozsianych po całym świecie. Nie należy też zakładać, że stanowi to przeszkodę w integracji. Realnym wyzwaniem jest brak umiejętności dialogu przełamującego wzajemne stereotypy i uprzedzenia oraz niechęć do wypracowania kompromisu.

Porównując tożsamość (de)konstruowaną z (re)konstruowaną, obrazowo można powiedzieć, że pierwsza budowana jest przez „odejmowanie” elementów kultury rodzimej i zastępowanie ich nowymi, a druga przez „dodawanie”. 
(De)konstruowaną tożsamość częściej obserwuje się w rodzinach niepełnych, gdy kobieta samotnie wychowuje dzieci i taka strategia wynika $z$ jej determinacji w radzeniu sobie za wszelką cenę, nierzadko $z$ narażeniem się na dezaprobatę członków własnej społeczności i samotność. Trudna sytuacja życiowa skłania do wyłamywania się z tradycyjnego kanonu zachowań i popularnego w kulturach Kaukazu podziału ról ze względu na płeć, w którym kobieta często jest bezwolna i całkowicie zależna od mężczyzny i jego klanu. W konsekwencji uniezależniania się kobiet postępuje rozłam między nimi a ich grupą etniczną, podtrzymującą tradycyjną formę relacji społecznych. Wykluczenie ze wspólnoty bywa poprzedzone złamaniem przez kobietę tabu kulturowego, na przykład wejściem w związek z mężczyzną innej narodowości lub „niewiernym” (niemuzułmaninem) ${ }^{18}$. Patowość i ryzyko tego sposobu konstruowania obrazu siebie w zmienionych warunkach kulturowych polega na tym, że brak intensywnych kontaktów z grupą własną i wykluczenie $z$ niej nie gwarantują „wkluczenia”, czyli przyjęcia przez społeczność „gospodarzy” - ekskluzja nie skutkuje w tym przypadku bezwarunkową inkluzją (zob. Firlit-Fesnak, Łotocki 2008).

Dlatego osoby takie nierzadko żyją „osobno”, pomiędzy jedną kulturą a drugą, nie przynależąc $\mathrm{w}$ pełni do żadnej z nich. Ich realna sytuacja $\mathrm{w}$ miejscu osiedlenia bywa niezwykle trudna i skomplikowana, a poradzenie sobie i udana akulturacja w głównej mierze zależą od cech osobowościowych. Szczególnie istotne i przydatne okazują się: odporność na stres, silna psychika, wysoka motywacja i jasno określone cele życiowe, wytrzymałość, łatwość nawiązywania kontaktów, determinacja. Kluczowe są też, zwłaszcza w okresie początkowym, czynniki materialno-bytowe ułatwiające adaptację i stabilizację: zakwaterowanie, zatrudnienie, elementarne świadczenia socjalne, nauka miejscowego języka i znajomość rosyjskiego lub innego języka europejskiego.

Osoby z dużym potencjałem osobowościowym i kapitałem społecznym mają największą szansę na sprostanie wyzwaniom akulturacyjnym i odnalezienie się w nowym miejscu. Zdarza się jednak, że nawet spełnienie wygórowanych warunków i zaangażowanie własnych zasobów w sukces przystosowawczy nie gwarantuje udanej adaptacji pozostałych członków rodziny. Sytuacje takie, jak wynika $z$ wypowiedzi udzielanych przez rozmówców, postrzegane są jako wyjątkowo dramatyczne i kwestionujące sens poniesionych kosztów emocjonalnych i wysiłków włożonych w przetrwanie. Egzemplifikuje to studium przypadku zarejestrowane podczas badań. Czeczeńska kobieta z przyznanym pobytem tolerowanym, samotnie wychowująca trójkę dzieci, w krótkim czasie po przyjeździe do Polski, z pomocą jednej z organizacji pozarządowych znajduje pracę i kończy szkołę wieczorową dającą jej możliwość lepszego zatrudnienia. Do-

18 Otwartość na małżeństwa i związki z cudzoziemcami, na przykład pochodzącymi z kultury osiedlenia, jak też akceptacja zmian $\mathrm{w}$ podziale tradycyjnych ról płciowych, to obszary szczególnie „wrażliwe” kulturowo, dobrze diagnozujące podejście akulturacyjne „gości” i dowodzące ich gotowości do integracji. 
brze sobie radzi, jest w stanie samodzielne utrzymać rodzinę, zdobywa zaufanie miejscowych i cieszy się uznaniem wśród swoich. Po pewnym czasie angażuje się $\mathrm{W}$ pomoc adaptacyjną innym uchodźcom, gdy lokalna fundacja proponuje jej pracę $\mathrm{w}$ charakterze asystenta kulturowego ${ }^{19}$. W trakcie wywiadu podkreśla, że jest spełniona i nie wyobraża sobie powrotu do wcześniejszego życia w swoim kraju, choć niewykluczone, że będzie musiała to rozważyć. Przyczyną są problemy z dziećmi, z którymi nie radzi sobie wychowawczo. Nie ma wśród nich posłuchu, przeciwstawiają się jej decyzjom, mają żal o niepodtrzymywanie więzi rodowych; poza tym doświadczają wielu problemów w szkole i wśród rówieśników, nie chcą się uczyć, słabo znają język polski, a jeszcze gorzej czeczeński, wykazują skłonności do „złego towarzystwa”, syn pije alkohol. Najgorsze jest dla niej jednak to, że zapowiedzieli, iż źle się czują w Polsce, nie chcą tu mieszkać i zamierzają wyjechać — syn do Czeczenii, a córka do rodziny ojca we Francji. Kobieta nie wyobraża sobie samotnego pozostania w obcym kraju, który zdążyła już nieźle oswoić, nie wyobraża sobie również powrotu w Kaukaz, nie mówiąc już o rozpoczynaniu wszystkiego od nowa w innym państwie europejskim. Nie ma pojęcia, co z nią będzie ani co będzie robić. Czasami myśli, że nie warto było wyłamywać się z tradycji, należało trzymać się „swoich” i powtórnie wyjść za mąż.

Konieczność zapewnienia bytu i bezpieczeństwa rodzinie jest dla samotnych, cudzoziemskich matek nie lada obciążeniem, które sprawia, że niekiedy nie przywiązują one dostatecznej wagi do enkulturacji dzieci i przekazywania im treści kulturowych czy do wychowywania w duchu narodowym. Nie znaczy to jednak, że taka potrzeba się nie ujawni i młode pokolenie nie zacznie na własną rękę szukać wspólnot dających poczucie zakorzenienia i przynależności. Czasami też kobiety świadomie decydują się na „europejskie wychowanie", wierząc, że to zapewni ich dzieciom lepsze i łatwiejsze życie oraz pomoże uniknąć problemów, których one same doświadczyły. Jak pokazały badania, nie zawsze tak jednak bywa i konsekwencje liberalizacji praktyk socjalizacyjnych w środowisku imigrantów, zwyczajowo przywykłych do bardziej restrykcyjnych reguł, bywają trudne do przewidzenia. Dotyczy to zarówno chłopców, jak i dziewcząt, choć w opinii moich rozmówców, wychowanie kobiet poza kręgiem własnej kultury jest znacznie bardziej skomplikowane, a ich start w dorosłe życie trudniejszy. Dlatego też matki-uchodźczynie dużo uwagi poświęcają uczeniu córek samodzielności i niezależności, co na ogół nie spotyka się z aprobatą rodaków. Taką dziewczynę trudniej też wydać za mąż, gdyż zarzut braku poszanowania norm kulturowych jest plamą na honorze i nie daje pewności „dobrego prowadzenia się" kandydatki na żonę i matkę. Sprawia to, że dylematy stojące przed uchodźczyniami posiadającymi potomstwo są niełatwe do rozwiązania, zwłaszcza że wiele z nich osobiście doświadczyło przemocy

19 Szczegółowo na temat roli asystenta kulturowego w społeczności dzieci czeczeńskich w polskiej szkole zob. Lachowicz 2010. 
związanej z płcią i supremacją mężczyzn i dlatego starają się przekazać córkom wartości, które ochronią je, jak wierzą, przed podobnym losem. Niestety, często czynią to nieumiejętnie i spotykają się z brakiem zrozumienia i zarzutami, że wypuszczają spod swoich skrzydeł potomstwo nieprzygotowane do podjęcia odpowiedzialności i pełnienia ról społecznych przypisanych im przez macierzystą kulturę.

Opisane wyżej typy tożsamości zaobserwowane wśród zamieszkałych w Polsce uchodźców z Kaukazu można uznać za przykłady modelowe. Najczęściej jednak spotyka się warianty pośrednie, znajdujące się między dwoma skrajnymi mechanizmami konstruowania obrazu siebie. Modele te stanowia, jak się wydaje, trafny predykator preferencji akulturacyjnych przybyszy, ich relacji z „gospodarzami” i obszarów potencjalnie konfliktogennych. Pomagają też wyjaśnić i zrozumieć przyczyny niektórych postaw i ich konsekwencje. Zasadnicza różnica między dwoma wariantami konstruowania samookreślenia młodych uchodźców polega na sile związku jednostki z grupą pochodzenia i rdzenną kulturą oraz skłonności (gotowości) do samodzielnego funkcjonowania poza ramami przez nią zakreślonymi. Tożsamość (re)konstruowana koreluje wysoko z kolektywizmem (poczuciem przynależności do wyobrażonej wspólnoty), a tożsamość (de) konstruowana $z$ indywidualizmem i niezależnością poznawczą. Warto pamiętać jednak, że tożsamość uchodźców jest dynamiczna i zaobserwowane tendencje mogą się zmieniać oraz przesuwać w różną stronę wyznaczonego umownie kontinuum. Sprzyjają temu między innymi: wydłużający się pobyt $\mathrm{w}$ nowym kraju, osobiste doświadczenia, zmieniające się cele i priorytety, sytuacja społeczno-ekonomiczna i polityczna $\mathrm{w}$ kraju pochodzenia i osiedlenia, a także prestiż własnej kultury oraz pozycja zajmowana przez jej przedstawicieli w kraju zamieszkania. Analiza zależności między tymi czynnikami obrazuje kierunek rozwoju identyfikacji implikowany zmianami któregokolwiek z nich. Stabilizowanie się polityczno-gospodarczej sytuacji kraju pochodzenia „gości” (również w znaczeniu nawiązywania współpracy na arenie międzynarodowej) oraz akceptacja przybyszy w nowym miejscu zamieszkania sprzyjają zróżnicowanym i niejednoznacznym identyfikacjom jednostki (mniej radykalnym i nie zespalającym zbyt silnie $z$ uproszczonym, stereotypowym wyobrażeniem o swoim kraju). Bezpieczne i przewidywalne warunki egzystencji cudzoziemców nie wywołują poczucia powinności replikowania własnej kultury, gdyż nie istnieją ani realne, ani wyobrażone powody jej zagrożenia. Profity wynikające $z$ „okopywania się” w artefaktach kulturowych — jak w przypadku osób preferujących tożsamość (re)konstruowaną — są mniejsze niż daje otwartość na nową kulturę i akceptacja zmiany. 
Badania przeprowadzone w środowisku dzieci uchodźczych z Czeczenii pokazały, że to, co najistotniejsze z punktu widzenia ich funkcjonowania w nowej kulturze, dokonuje się przede wszystkim w środowisku rodzinno-etnicznym, w procesie enkulturacji. Oznacza to, że choć w sferze zewnętrznej obserwuje się symptomy postępującej akulturacji, to nie gwarantuje to, iż zachodzi ona również w sferze wewnętrznej - odnoszącej się do postaw, przekonań i wartości. Skłania to do refleksji nad rzeczywistym wpływem działań integracyjnych adresowanych do cudzoziemców i realizowanych przez oddziaływania na poziomie edukacji szkolnej, imprez kulturalnych i warsztatów adaptacyjnych. Jak pokazują obserwacje, egzystowanie w dwóch różnych rzeczywistościach aksjonormatywnych na dłuższą metę jest niezwykle trudne (jeśli w ogóle możliwe) i w którymś momencie trzeba się zdecydować się na jeden „kod kulturowy", zwłaszcza jeśli celem jest partycypacja w życiu społecznym. Realne wyzwanie polega na wypracowaniu porozumienia dotyczącego zasad zgodnej, satysfakcjonującej i partnerskiej koegzystencji kulturowej na danym terytorium.

Niewątpliwie też do akulturacji uchodźców należy podchodzić jednostkowo, uwzględniać szeroki kontekst oddziaływań kształtujących ich tożsamość i nie uogólniać wniosków na całą społeczność lub grupę etniczną, gdyż różnice między członkami diaspor transnarodowych bywają zasadnicze. Brak dostępu do treści przekazywanych w toku enkulturacji osłabia możliwość oceny stopnia ich przystosowania do kultury kraju osiedlenia. Założenie, że kultura kraju przyjmującego jest na tyle atrakcyjna, iż zostanie przyjęta „W całości” i bez oporu, jest „pobożnym życzeniem”, do tego nacechowanym etnocentryczne. Bardziej prawdopodobne jest, że wygórowane oczekiwania asymilacyjne przyniosą skutek przeciwny do zamierzonego, powodując na przykład radykalizację postaw religijnych i zamknięcie w obrębie własnej wspólnoty.

Wróćmy do wątku inicjującego, czyli wydarzeń bostońskich, który ilustruje między innymi fakt, że akulturacja cudzoziemców i przystosowanie kulturowe nie świadczy jeszcze o zintegrowaniu ze społeczeństwem przyjmującym. Można bowiem doskonale znać daną kulturę i swobodnie się w niej poruszać, ale się $z$ nią nie identyfikować i nie internalizować jej na poziomie wartości. Przeciwnie - można tworzyć i wzmacniać identyfikacje antagonizujące ze społecznością przyjmującą i pogłębiające różnice między obiema kulturami. Skutki tego niekiedy ujawniają się dopiero w kolejnych pokoleniach migrantów, które pozornie wydają się dobrze zaadaptowane. Odpowiedzialność za to $\mathrm{w}$ symbolicznym sensie tkwi w obu procesach - enkulturacji i akulturacji, które nierzadko są przeciwstawiane, jakkolwiek powinny być równoległe i wzajemnie uzupełniające. Wyjaśnia to $\mathrm{w}$ pewnym stopniu, dlaczego „amerykańska żona” Tamerlana Carnajewa (studenta Massachusetts Institut) i jej rodzice przyznali $\mathrm{w}$ szoku, że tak naprawdę nigdy go nie znali i choć wydawał się takim „normalnym” chłopakiem, to był kimś zupełnie in- 
nym $^{20}$. Idąc krok dalej w interpretacjach (oby nie za daleko), można przytoczyć również wypowiedzi matki czeczeńskich braci, która powiedziała, że to „Ameryka uczyniła z jej synów przestępców i terrorystów". Czy rzeczywiście jest to wyczerpująca diagnoza przyczyn stojących za tragicznym aktem terroryzmu, pozostaje kwestią do dyskusji, której nie sposób w tym miejscu rozstrzygnąć.

\section{BIBLIOGRAFIA}

Adger-Adajew Issa, 2005, Kamienie mówią. Dzieje i kultura Czeczenów, tłum. Klara Brodacka, Instytut Kultury Narodów Kaukazu, Warszawa.

Aronson Elliot, 1997, Człowiek istota spoteczna, tłum. Józef Radzicki, Wydawnictwo Naukowe PWN, Warszawa.

Aronson Elliot, 2007, Social Animal, Worth Publishers, New York.

Bauman Zygmunt 2004, O tarapatach tożsamości w ciasnym świecie, w: Wojciech Kalaga (red.), Dylematy wielokulturowości, Univesitas, Kraków.

Bauman Zygmunt, 2005, Tożsamość. Rozmowy z Benedetto Vecchim, tłum. Jacek Łaszcz, Gdańskie Wydawnictwo Psychologiczne, Gdańsk.

Bauman Zygmunt, 2007, Tożsamość ze sklepu, tożsamość ze spiżarni, w: Agnieszka Gromkowska-Melosik (red.), Kultura popularna i (re)konstrukcje tożsamości, Wyższa Szkoła Humanistyczna w Lesznie, Poznań-Leszno.

Bourhis Richard Y., Moïse Léna Céline, Perreault Stéphane, Senécal Sacha, 1997, Towards an Interactive Acculturation Model: A Social Psychological Approach, „International Journal of Psychology”, t. 32, nr 6, s. 369-386.

Brehm Jack W., 1993, The Intensity of Emotion, „Personality and Social Psychology Review”, t. 3, nr 1, s. 2-22 (doi:10.1207/s15327957pspr0301_1).

Certeau de Michel, 1982, The Practice of Everyday Life, University of California Press, Berkeley.

Certeau de Michel, 2008, Wynaleźć codzienność. Sztuki działania, tłum. Katarzyna Thiel-Jańczuk, Wydawnictwo Uniwersytetu Jagiellońskiego, Kraków.

Elliott Anthony, 2007, Koncepcje „ja”, tłum. Sławomir Królak, Sic!, Warszawa.

Firlit-Fesnak Grażyna, 2008, Spoteczność lokalna wobec cudzoziemców poszukujących ochrony w Polsce, w: Grażyna Firlit-Fesnak, Łukasz Łotocki (red.), Czym chata bogata... Pomoc dla cudzoziemców poszukujących ochrony w Polsce $w$ świetle badań spoteczności i instytucji lokalnych, ASPRA-JR, Warszawa.

Garewicz Jan, 1983, Pokolenie jako kategoria socjofilozoficzna, „Studia Socjologiczne”, nr 1.

Glick Thomas, 2006, Aculturation, w: Thomas Barfield (red.), The Dictionary of Anthropology, Blackwell, Oxford.

Hammack Phillip L. 2008, Narrative and the Cultural Psychology of Identity, „Personality and Social Psychology Review”, t. 12, nr 3, s. 222-247 (doi: 10.1177/1088868308316892).

Herskovits Melvill, 1948, Man and His Works: The Science of Cultural Anthropology, A. A. Knopf, New York.

Kawula Stanisław, Brągiel Józefa, Janko Andrzej, 1997, Socjologia rodziny, Wydawnictwo Adam Marszałek, Torun.

Kluckhohn Clyde, Murray Henry A., 1953, Personality in Nature, Society and Culture, A. A. Knopf, New York.

Kłoskowska Antonina, 1971, Rodzina jako czynnik transmisji i twórczości kulturalnej, „Kwartalik Pedagogiczny", nr 4.

20 Zob. np. http://wiadomosci.wp.pl/kat,1356,title,Dzochar-Carnajew-jestem-niewinny,wid,15 804056,wiadomosc.html?ticaid=1117e6\#czytajdalej [12.10.2013]. 
Kłoskowska Antonina, 1992, Tożsamość i identyfikacja narodowa w perspektywie historycznej i psychologicznej, „Kultura i Społeczeństwo”, nr 1.

Kłoskowska Antonina, 1996, Kultury narodowe u korzeni, Wydawnictwo Naukowe PWN, Warszawa.

Kość-Ryżko Katarzyna, Czerniejewska Izabela, 2013, Oblicza integracji uchodźców w Polsce. Na przykładzie analizy funkcjonowania ośrodków w Grupie i Czerwonym Borze, w: Janusz Balicki, Mariusz Chamarczuk (red.), Wokót problematyki migracyjnej. Kultura przyjęcia, Ministerstwo Rozwoju Regionalnego, Warszawa.

Lachowicz Bogumiła, 2010, Asystent międzykulturowy - nowe rozwiązanie starych problemów. Przykład z Coniewia, Forum na rzecz Różnorodności Społecznej, Seria Wydawnicza „Maieutike” nr 14.

Mead George Herbert, 1975, Umyst, osobowość i społeczeństwo, tłum. Zofia Wolińska, Państwowe Wydawnictwo Naukowe, Warszawa,

Mead Margaret, 1963, Papers in Honor of Melville J. Herskovits: Socialization and Enculturation, „Current Anthropology", t. 4, nr 2, s. 184-188.

Politkowska Anna, 2007, Udręczona Rosja. Dziennik buntu, tłum. Anna Michalska, Oficyna Literacka Noir sur Blanc, Warszawa.

Rafalik Norbert, 2012, Cudzoziemcy ubiegajacy się o nadanie statusu uchodźcy w Polsce - teoria a rzeczywistość (praktyka) (stan prawny na dzień 31 grudnia 2011 r.), CMR Working Papers, nr 55/113.

Rhum Michael, 2006, Enculturation, w: Thomas Barfield (red.), The Dictionary of Anthropology, Blackwell, Oxford.

Rostowska Teresa, 1994, Rola modelowania $w$ procesie socjalizacji dziecka $w$ rodzinie, „Problemy Rodziny", nr 3.

Sadowski Andrzej, Czerniawska Mirosława, 1999, Tożsamość Polaków na pograniczach, Wydawnictwo Uniwersytetu w Białymstoku, Białystok.

Seierstad Åsne, 2009, Dzieci Groznego, tłum. Iwona Zimnicka, Wydawnictwo W.A.B., Warszawa. Skorny Zbigniew, 1987, Proces socjalizacji dzieci i mtodzieży, WSiP, Warszawa.

Taylor Stephanie, 2005, Identity Trouble and Opportunity in Women's Narratives of Residence, „Auto/Biography”, t. 13, nr 3, s. 249-265.

Tillmann Klaus-Jürgen, 1996, Teorie socjalizacji. Społeczność, instytucja, upodmiotowienie, tłum. Grzegorz Bluszcz, Bartek Miracki, Wydawnictwo Naukowe PWN, Warszawa.

Vertovec Steven, 2012, Transnarodowość, tłum. Izabela Kołbon, Wydawnictwo Uniwersytetu Jagiellońskiego, Kraków.

Whitehead Charles, 2010, Social Mirror Theory, the Arts, and the Evolution of Human Self-Consciousness, „Consciousness, Literature and the Arts”, nr 11/3.

Wolicki Marian 1983, Naśladownictwo, identyfikacja i modelowanie jako czynniki rozwoju społecznego, „Problemy Rodziny”, nr 5.

Wybieralski Michał, 2014, Hidżab jest hipsterski, czyli co wolno muzutmanom w USA (www.wyborcza.pl/ 1,75477,15229938,Hidzab_jest_hipsterski_czyli_co_wolno_muzulmankom.html [12.6.2014]).

Ząbek Maciej, Łodziński Sławomir, 2008, Uchodźcy w Polsce. Próba spojrzenia antropologicznego, ASPRA-JR, Warszawa.

Ziemska Maria, 1979, Rodzina a osobowość, Wiedza Powszechna, Warszawa.

\section{CONSTRUCTING IDENTITY IN CONDITIONS OF CULTURAL FOREIGNNESS: THE CASE OF UNDER-AGE REFUGEES FROM CHECHNYA IN POLAND}

\section{Summary}

Research conducted by the author in the years 2009-2014 among the children of refugees from Chechnya has shown that what is most important in terms of their func- 
tioning in the new culture occurs primarily in the family/ethnic environment, in the process of enculturation. This means that even though manifestations of progressing acculturation may be observed in the external sphere, this does not guarantee that the process is also occurring in the internal sphere of attitudes, convictions, and values. In this connection the writer's attention was drawn to how under-age refugees from post-Soviet lands create a sense of identity and ethnic belonging. In particular, she considered the degree to which being a refugee and the situation in which these children find themselves have a formative influence on their self-identification. External indicators of ethnic, cultural, and religious identification were also analyzed. The author has thereby established the model-based on the two alternative strategies of reconstruction and deconstruction-by which young refugees create their self-identification.

\section{Key words / słowa kluczowe}

refugees / uchodźcy; identity / tożsamość; ethnicity / etniczność; cultural adaptation / adaptacja kulturowa; Chechens in Poland / Czeczeni w Polsce 